\title{
Synthesis, Characterization and Cytotoxic activity of New Indole Schiff Bases, Derived From 2-(5-Chloro-3,3-dimethyl- 1,3-dihydro-indol-2-ylidene)-Malonaldehyde with Substituted aniline
}

\author{
ASEEL FAEQ GHAIDAN ${ }^{1 *}$, FADHIL LAFTA FARAJ ${ }^{2 * *}$ and ZAYNAB SAAD ABDULGHANY ${ }^{1 *}$ \\ ${ }^{1}$ Department of Molecular biology, Iraqi Center for Cancer and Medical Genetic Research, University of \\ AL-Mustansiriyah, Iraq. \\ ${ }^{2}$ Department of Chemistry, Faculty of Science, University of Diyala, Diyala Governorate, Iraq. \\ ${ }^{*}$ Corresponding author E-mail: fadhillaftafaraj@gmail.com
}

http://dx.doi.org/10.13005/ojc/340119

(Received: October 28, 2017; Accepted: December 20, 2017)

\begin{abstract}
Series of new compounds of indole Schiff base derivatives have been synthesized by reaction of 2-(5-Chloro-3,3-dimethyl-1,3-dihydro-indol-2-ylidene)-malonaldehyde with aniline substituted. The chemical structures of the synthesized compounds were characterized by TLC, FT-IR, ${ }^{1} \mathrm{H},{ }^{13} \mathrm{C}$ NMR and APT ${ }^{13} \mathrm{C}$ NMR. The in vitro anticancer activity of the new synthesized compounds tested against- AMJ breast cancer cell line. The revealed data showed that compounds have promising anticancer activity against AMJ13 cell line at low concentrations.
\end{abstract}

Keywords: Schiff bases, Aniline substituted, Aldehyde, Cytotoxic Activity.

\section{INTRODUCTION}

Schiff bases are important compounds in the chemistry and biochemistry fields due to their biological activities ${ }^{1}$. Schiff bases which are a class of compounds containing an azomethine group $(-\mathrm{C}=\mathrm{N}-)$ as functional group have focus attention for a long time due to their medicinal and pharmaceutical activities ${ }^{2}$. Schiff bases were first reported by Hugo Schiff in 1864, they are formed by the condensation reaction of aldehydes or ketones with primary amines in the presence of acid as a catalyst ${ }^{3}$. They have many applications in different fields for example: antibacterial, antifungal, and antitumor activity ${ }^{4}$.

This is an $\mathbf{2}$ Open Access article licensed under a Creative Commons Attribution-NonCommercial-ShareAlike 4.0 International License (https://creativecommons.org/licenses/by-nc-sa/4.0/ ), which permits unrestricted NonCommercial use, distribution and reproduction in any medium, provided the original work is properly cited. 
Schiff bases obtain from different organic heterocyclic compounds chiefly those consisting of indole molecule, There is an important class of organic heterocyclic compounds because they have abroad applications for example, antioxidant, anticancer ${ }^{5}$, Antibacterial, antifungal, anti-inflammatory and antiviral properties ${ }^{6}$.

Cancer is a disease that make cells growth in the body out of control; the most common types of cancer are breast, lung, colon and prostate cancer ${ }^{7}$. When it is start in the breast then it is called breast cancer $(\mathrm{BC})^{8}$.
$\mathrm{BC}$ is one of the most common diagnosed types of cancer in women around the world an inducing to cancer death with almost 1.67 million new cases of cancer and more than 500,000 BC deaths predicted to have appeared in $2012^{9}$.

Thus, in our current research we were aim to synthesis three new indole Schiff bases derivatives as illustration in Fig.1, and tested their cytotoxic activity against $-\mathrm{AMJ13}$ breast cancer cell line ${ }^{10}$<smiles>CC1(C)C(C=O)=C(C=O)Nc2ccc(Cl)cc21</smiles><smiles>[R2]c1ccc(N)c(F)c1</smiles>

1-equ.

$$
\begin{aligned}
& \mathrm{R}_{1}=\mathrm{CH}_{3}, \mathrm{H} \\
& \mathrm{R}_{2}=\mathrm{Br}, \mathrm{CH}_{3}, \mathrm{H}
\end{aligned}
$$<smiles>[R2]c1ccc(N=C/C(C=O)=C2\Nc3ccc(Cl)cc3C2(C)C)c([R1])c1</smiles>

Fig. 1. The synthetic pathway to a new Schiff bases

\section{EXPERIMENTAL}

\section{Chemistry part Instruments}

Melting points were measured by using open capillary melting point device and the purification were taken by using Thin layer Chromatography was performed by using Silica gel sheets and the spots were observed using florescence analysis cabinet model CM-10. IR spectra were recorded on Perkin-Elmer spectrum version 1 in Diyala University, ${ }^{1} \mathrm{H},{ }^{13} \mathrm{C}$ NMR and $\mathrm{APT}^{13} \mathrm{C}$ NMR spectra were recorded in DMSO on a Bruker $400 \mathrm{MHz}$ spectrometer, at $400 \mathrm{MHz}$ for ${ }^{1} \mathrm{H}$ NMR and at $100 \mathrm{MHz}$ for ${ }^{13} \mathrm{C}$ NMR and APT spectra in Jordan, University of science and technology, College of science, Irbid city .

\section{Chemicals and solvent}

All the chemicals and solvents used in this research were obtained from different companies; they were used as received without further purification Such 4-chlorophenyl hydrazine hydra chloride, methyl isobutyl ketone, Dimethyl formamide, and Dimethyl sulfoxide were obtained from Aldrich.
Phosphoryl chloride, 4-Bromoaniline and 2,4dimethyl aniline were obtained from Merck \& Co. Aniline and Sodium hydroxide were obtained from Thomas baker. Glacial acetic acid was obtained from $\mathrm{BDH}$. All organic solvent obtained from Scharlau. 2-(5-Chloro-3,3-dimethyl-1,3-dihydro-indol-2ylidene)-malonaldehyde was synthesized with modification of a procedure described by ${ }^{8}$. As shown in Figure (2)

\section{Synthetic methods}

Synthesis of 2-(5-Chloro-3,3-dimethyl-1,3dihydro-indol-2-ylidene)-3-phenyliminoPropionaldehyde(1). As illustrated in Figure. 3.

A solution of $(0.75 \mathrm{~g}, 3 \mathrm{mmol})$ of $2-(5-$ Chloro-3,3-dimethyl-1,3-dihydro-indol-2-ylidene)malonaldehyde was dissolved in ethanol $30 \mathrm{~mL}$ and $(0.28 \mathrm{~g}, 3 \mathrm{mmol})$ of phenyl amine was dissolved in ethanol $10 \mathrm{~mL}$ and then added glacial acetic acid $2 \mathrm{~mL}$ to the solution. The mixture was stirring in a water bath at $78^{\circ} \mathrm{C}$ for $2 \mathrm{~h}$. Yellow crystals precipitate was formed, filtered off, washed with ethanol and dried in oven at $78{ }^{\circ} \mathrm{C}$. The purity of this compound was determined by using TLC with pre-coated silica 
gel, which gave one spot. . IR data in $\left(\mathrm{cm}^{-1}\right)$ : $2968 v$ ( $\mathrm{CH}$ aromatic), 2705v $(\mathrm{CH}$ aldehyde, $1672 v$ $(\mathrm{CH}=\mathrm{O}), 1628 v(\mathrm{C}=\mathrm{C}), 1599 v(\mathrm{CHN}), 1402 v\left(\mathrm{CH}_{3}\right)$ $1230 v(\mathrm{C}-\mathrm{N}), 820 v(\mathrm{C}-\mathrm{Cl})$ and $754 \mathrm{v}(\mathrm{C}-\mathrm{H}$ bending).


$9.42(\mathrm{~s}, 1 \mathrm{H}, \underline{H C O}), 8.69(\mathrm{~s}, 1 \mathrm{H}, \underline{H C N}), 7.63-7.23$ $(8 \mathrm{H}, \mathrm{Ar}-\underline{H})$, and1.60 (s,6H, 2x C $\left.\underline{\mathrm{H}}_{3}\right) \cdot{ }^{13} \mathrm{CNMR}$ $(100 \mathrm{MHz}, \mathrm{DMSO}, \delta \mathrm{ppm}): 188.32(\underline{C}=\mathrm{O}), 183.62$ $(\mathrm{NH}-\underline{C}=\mathrm{C}), 156.76(\underline{\mathrm{CH}}=\mathrm{N}), 149.60,147.64,139.51$, 129.83, 129.53, 127.44, 125.45, 121.77, 119.98 and $118.17(\underline{A r}-\underline{C H}), 108.19(\mathrm{O}=\mathrm{C}-\underline{C}=\mathrm{C}), 54.41\left(\mathrm{CH}_{3}\right.$ $\left.\mathrm{CCH}_{3}\right), 21.64\left(\mathrm{~s}, 6 \mathrm{H}, 2 \times \underline{C} \mathrm{H}_{3}\right)$. APT ${ }^{13} \mathrm{CNMR}$ shown signals for $\mathrm{CH}$ and $\mathrm{CH}_{3}$ appeared at negative side (below base line of the spectrum) 188.32, $156.47,129.56,127.17,125.18,121.50,119.70$, 117.90 and 21.38 whereas quaternary carbons and carbons deuterated DMSO solvent were observed at positive side (above base line of the spectrum) 183.62, 149.33, 147.38, 139.25, 129.27, 107.92 and 54.13 .

Synthesis of 3-(4-Bromo-phenylimino)-2(5-chloro-3,3-dimethyl-1,3-dihydro-indol-2-ylidene)Propionaldehyde(2). As shown in Figure. 4.


hydrzinhydrochloride

Fig. 2. The synthetic pathway of 2-(5-Chloro-3,3-dimethyl-1,3-dihydro-indol-2-ylidene)-malonaldehyde<smiles>CC(=O)OC(=O)O</smiles>

Fig. 3. Synthetic pathway of 2-(5-Chloro-3,3-dimethyl-1,3-dihydro-indol-2-ylidene)-3-phenyliminopropionaldehyde (1).<smiles>CC1(C)C(C=O)=C(C=O)Nc2ccc(Cl)cc21</smiles><smiles>CC(=O)OC1=C(C=O)C(C)(C)c2cc(Cl)ccc2N1</smiles>

(2)

Fig. 4. Synthetic pathway of 3-(4-Bromo-phenylimino)-2-(5-chloro-3,3- dimethyl-1,3-dihydro-indol-2ylidene)- Propionaldehyde (2) 
A solution of $(0.75 \mathrm{~g}, 3 \mathrm{mmol})$ of $2-(5-$ Chloro-3,3-dimethyl-1,3-dihydro-indol-2-ylidene)malonaldehyde was dissolved in ethanol $30 \mathrm{~mL}$ and $(0.51 \mathrm{~g}, 3 \mathrm{mmol})$ of 4-Bromo-phenylamine was dissolved in ethanol $10 \mathrm{~mL}$ and then added glacial acetic acid $1 \mathrm{~mL}$ to the solution. The mixture was refluxed in a water bath at $78^{\circ} \mathrm{C}$ for 3 hours. A solvent was reduced to one quarter; yellow precipitate was formed, filtered off, washed with ethanol and dried in oven at $78^{\circ} \mathrm{C}$. The purity of this compound was determined by using TLC with pre-coated silica gel, which gave one spot. IR data in $\left(\mathrm{cm}^{-1}\right): 2961 \mathrm{v}(\mathrm{CH}$ aromatic), $2712 v(\mathrm{CH}$ aldehyde), $1665 \mathrm{v}(\mathrm{CH}=\mathrm{O})$, $1621 v(\mathrm{C}=\mathrm{C}), 1581 v(\mathrm{CHN}), 1394 v\left(\mathrm{CH}_{3}\right), 1233 v$ (C-N), $816 v(\mathrm{C}-\mathrm{Cl})$ and $769 v\left(\mathrm{C}-\mathrm{H}\right.$ bending). ${ }^{1} \mathrm{HNMR}$ (400 MHz,DMSO, $\delta p p m) .13 .95(\mathrm{~s}, 1 \mathrm{H}, \mathrm{N} \underline{H}$ ), 9.43 (s,1H, $\underline{H C O}), 8.65(\mathrm{~s}, 1 \mathrm{H}, \underline{H C N}), 7.66-7.33(7 \mathrm{H}, \mathrm{Ar}-\underline{H})$, and1.59 (s,6H, 2x $\left.\mathrm{CH}_{3}\right) .{ }^{13} \mathrm{CNMR}(100 \mathrm{MHz}$, DMSO,<smiles>CC1(C)C(C=O)=C(C=O)Nc2ccc(Cl)cc21</smiles>

1equ<smiles>CC1=CC(C)=C(N)C=[C+]1</smiles>

1equ $\delta p p m): 187.98(\underline{C}=0), 182.96(\mathrm{NH}-\underline{C}=\mathrm{C}), 156.56$ $(\mathrm{CH}=\mathrm{N}), 148.92,147.20,139.07,132.17,129.21$, $127.14,121.48,120.08,119.53,117.03(\underline{A r}-\underline{C H})$, 108.11 $(\mathrm{O}=\mathrm{C}-\underline{\mathrm{C}}=\mathrm{C}), 53.92\left(\mathrm{CH}_{3} \underline{\mathrm{CH}_{3}}\right)$ and 21.46 $\left(2 \times \mathrm{CH}_{3}\right)$.APT ${ }^{13} \mathrm{CNMR}$ shown signals for $\mathrm{CH}$ and $\mathrm{CH}_{3}$ appeared at negative side (below base line of the spectrum) $187.87,156.61,132.18,127.14$, $121.47,120.17,119.46$ and 116.96 whereas quarternary carbons and carbons deuterated DMSO solvent were observed at positive side (above base line of the spectrum) 183.03.149.05, 147.26, 132.43, 129.09, 116.96, 108.08 and 53.90.

Synthesis of 2-(5-Chloro-3,3-dimethyl-1,3dihydro-indol-2-ylidene)-3-(2,4-dimethylphenylimino)-propionaldehyde (3). As shown in Figure 5.<smiles>CC(=O)OCC(=O)O</smiles>

(3)

Fig. 5. Synthetic pathway of 2-(5-Chloro-3,3-dimethyl-1,3-dihydro-indol-2-ylidene)-3-(2,4-dimethyl phenylimino)-propionaldehyde (3)

A solution of $(0.7 \mathrm{~g}, 2.8 \mathrm{mmol})$ of $2-(5-$ Chloro-3,3-dimethyl-1,3-dihydro-indol-2-ylidene)malonaldehyde was dissolved in ethanol $25 \mathrm{~mL}$ and $(0.33 \mathrm{~g}, 2.8 \mathrm{mmol})$ of 1,4-dimethyl aniline was dissolved in ethanol $10 \mathrm{~mL}$ and then added glacial acetic acid $1 \mathrm{~mL}$ to the solution. The mixture was refluxed in a water bath at $78^{\circ} \mathrm{C}$ for 5 hours. A solvent was reduced to one quarter; yellow precipitate was formed, filtered off, washed with ethanol and dried in oven at $78^{\circ} \mathrm{C}$. The purity of this compound was determined by using TLC with pre-coated silica gel, which gave one spot. IR data in $\left(\mathrm{cm}^{-1}\right):-3049 \mathrm{v}$ $(\mathrm{NH}), 2961 v(\mathrm{CH}$ aromatic), $2720 v(\mathrm{CH}$ aldehyde, $1669 v(\mathrm{CH}=\mathrm{O}), 1625 v(\mathrm{C}=\mathrm{C}), 1603 v(\mathrm{CHN}), 1398$ $v\left(\mathrm{CH}_{3}\right), 1239 v(\mathrm{C}-\mathrm{N}), 809 v(\mathrm{C}-\mathrm{Cl})$ and780v $(\mathrm{C}-\mathrm{H}$ bending), ${ }^{1} \mathrm{HNMR}(400 \mathrm{MHz}, \mathrm{DMSO}, \delta \mathrm{ppm}) .14 .09$ (s, $1 \mathrm{H}, \mathrm{N} \underline{H}), 9.40(\mathrm{~s}, 1 \mathrm{H}, \underline{H C O}), 8.64(\mathrm{~s}, 1 \mathrm{H}, \underline{H C N}), 7.56-$ $7.11(6 \mathrm{H}, \mathrm{Ar}-\underline{H}), 2.40$ and $2.27\left(\mathrm{~s}, 6 \mathrm{H}, 2 \times \mathrm{CH}_{3}\right)$ and $1.59\left(\mathrm{~s}, 6 \mathrm{H}, 2 \times \mathrm{CH}_{3}\right) ;{ }^{13} \mathrm{CNMR}(100 \mathrm{MHz}$, DMSO, $\delta p p m): 187.81(\underline{C}=\mathrm{O}), 183.60(\mathrm{NH}-\underline{C}=\mathrm{C}), 155.71$ $(\mathrm{CH}=\mathrm{N}), 149,45,147.41,135.21,134.23,131.42$, $129.25,127.56,127.23,126.86,121.61,119.05$ and $115.09(\underline{A r}-\underline{C H}), 108.01 \quad(\mathrm{O}=\mathrm{C}-\underline{C}=\mathrm{C}), 54.23$ $\left(\mathrm{CH}_{3} \mathrm{CCH}_{3}\right), 21.26\left(2 \times \mathrm{CH}_{3}\right), 20.17\left(\mathrm{o}-\mathrm{CH}_{3}\right)$ and $17.34\left(p-\mathrm{CH}_{3}\right)$. APT ${ }^{13} \mathrm{CNMR}$ shown signals for $\mathrm{CH}$ and $\mathrm{CH}_{3}$ appeared at negative side (below base line of the spectrum) $187.81,155.66,127.21,121.58$, 119.03 and $115.13,21.26,20.17$ and 17.34 whereas quaternary carbons and carbons deuterated DMSO solvent were observed at positive side (above base line of the spectrum) $183.60,149.43,147.49,135.23$, $134.23,131.40,127.55,126.87,108.00$ and 54.20.

\section{Biological part}

Two types of cell lines have been used in this Study. Breast cancer cell line (AMJ13) and broblastic and epithelial cells with normal chromosomal pictures (REF) as normal murine cell 
lines were used. Both of them are locally established in ICCMGR and they are maintained for use.

\section{Determination of solubility of compounds tested for in vitro cytotoxicity}

Solubility assessment of synthesized compounds was carried out according to standard test method protocol ${ }^{12}$. The three new compounds were dissolved in dimethyl sulfoxide and diluted with nutrition medium RPMI-1640 to the desired concentrations $(10 \mu \mathrm{g} / \mathrm{ml}, 20 \mu \mathrm{g} / \mathrm{ml}, 40 \mu \mathrm{g} / \mathrm{ml}$ and $60 \mu \mathrm{g} / \mathrm{ml}$ ). Only freshly prepared solutions were used in experiments.

Both cell lines(AMJ13 and REF) are cultured in RPMI-1640 media that contains $10 \%$ fetal bovine serum, glutamine (2 $\mathrm{mmol} / \mathrm{L}$ ), streptomycin $(100 \mathrm{U} / \mathrm{ml})$ and penicillin $(100 \mathrm{U} / \mathrm{ml})$, then incubated in $5 \% \mathrm{CO}_{2}$ at $37{ }^{\circ} \mathrm{C}$ for 24 hours. In this time the cells will grow and become monolayer The confluent monolayer cells treated with $1 \mathrm{ml}$ of trypsin/versine to provide suspension of cells, then add $10 \mathrm{ml}$ of prepared media. About $200 \mu \mathrm{l}$ of the cells were culture on clean sterile 96- well microtiter plate then let the cells for 24 hours. to make single monolayer to be ready to be treated with the our three new compounds.

Exposure day, decant the media from the cells and add $200 \mu \mathrm{l}$ from the dilutions new compounds. Each concentration was triplicate and returns the microtiter plates to the incubator. Leave wells contains only cells without treatment contains serum free media representing control cells. Three different exposure times of the cells were included in this research, 24, 48 and 72 hours. The protocol of handing and treating the cells was prepared as described by Butler, $2004^{13}$.

\section{Cell Viability Assay}

The cytotoxicity was determined after each exposure time using crystal violet. Decant the contents of microliter plate, add 200 il of the crystal violet to each wells of the treated cells for $20 \mathrm{~min}$. in the incubator at $37^{\circ} \mathrm{C}$. The crystal violet will stain the nuclei of the viable cell and the color will be visible to the eye. Then the plates were read by ELISA reader at $495 \mathrm{~nm}$. And then the inhibition rate was calculated using the following equation as recommended by ${ }^{14}$.

$\%$ Growth Inhibition $=(\mathrm{C}-\mathrm{T}) / \mathrm{C} \times 100 \%$

Were, C represent absorbance of control and $\mathrm{T}$ absorbance of sample.

\section{Statistical Analysis}

In this study, we used student t-test to determine the differences between the concentrations in each cell line and to determine the differences between two cells in each exposure time. The probability $\mathrm{p}$ was determined to be $\mathrm{p} \leq 0.05$. Graph Pad Prism V6 was used to determine this statistical test. Excel 2010 sheet was used to draw the curves.

\section{RESULTS AND DISCUSSION}

The new synthesized compounds were subjected to TLC; spectral studies like HNMR, ${ }^{13} \mathrm{CNMR}, \mathrm{APT}{ }^{13} \mathrm{CNMR}$ and FTIR, and their results are discussed below. The physical properties such as the percentage yield and melting point of the compounds (1, 2 and 3) are represented in Table No.1

Table. 1: Physical properties of the synthesized compounds (1-3)

\begin{tabular}{lcccc} 
Compound No. & Molecular formula & Molecular weight & Percentage Yield & Melting Point ${ }^{\circ} \mathrm{C}$ \\
\hline 1 & $\mathrm{C}_{19} \mathrm{H}_{17} \mathrm{CIN}_{2} \mathrm{O}$ & $(324.80)$ & $82 \%$ & $279-281^{\circ} \mathrm{C}$ \\
2 & $\mathrm{C}_{19} \mathrm{H}_{16} \mathrm{BrClN}_{2} \mathrm{O}$ & $(403.70)$ & $75 \%$ & $171-173^{\circ} \mathrm{C}$ \\
3 & $\mathrm{C}_{21} \mathrm{H}_{21} \mathrm{CIN}_{2} \mathrm{O}$ & $(352.86)$ & $84 \%$ & $169-170^{\circ} \mathrm{C}$
\end{tabular}

\section{IR Study}

The IR results of the synthesized compounds were shown absorption bands in the
$4,000-400 \mathrm{~cm}^{-1}$ range, especially the new functional group (azomethine group $\mathrm{CH}=\mathrm{N}$ ) at 1599 $\mathrm{cm}^{-1}, 1581 \mathrm{~cm}^{-1}$ and $1603 \mathrm{~cm}^{-1}$ for synthesized 
compounds (1,2 and 3 ) respectively ${ }^{15}$. which approved to formation the accuracy chemical structure of synthesized compounds. Also strong absorption band at $1672 \mathrm{~cm}^{-1}, 1665 \mathrm{~cm}^{-1}, 1669 \mathrm{~cm}^{-1}$ for compounds(1, 2and 3 ) respectively which were belonged to $(\mathrm{C}=\mathrm{O})$ of the carbonyl group ${ }^{16}$. As well as stretching frequency at 1628 and $1621 \mathrm{~cm}^{-1}$ for compounds ( 1 and 2) respectively, $1625 \mathrm{~cm}^{-1}$ for compounds (3) were referred to $(\mathrm{C}=\mathrm{C})$ group $^{17}$. at the same time the synthesized compounds were appeared an absorption bands at $1230 \mathrm{~cm}^{-1} 1233$ $\mathrm{cm}^{-1}$ and $1239 \mathrm{~cm}^{-1}$ which attributed to (C-N) groups of synthesized compounds (1,2 and 3) respectively ${ }^{18}$.

Finally, absorption band at $1402 \mathrm{~cm}^{-1}$ and $1394 \mathrm{~cm}^{-1}$ for compounds (1 and 3) respectively and $1398 \mathrm{~cm}^{-1}$ for compounds (2) were appointed to $\left(\mathrm{CH}_{3}\right)$ group ${ }^{19}$. All these main absorption bands are approved the chemical structures of the synthesized compounds (1, 2 and 3 ).

\section{NMR Study}

${ }^{1} \mathrm{H}-\mathrm{NMR},{ }^{13} \mathrm{C}$-NMR and APT ${ }^{13} \mathrm{C}-\mathrm{NMR}$ spectra were reported in DMSO (dimethyl sulfoxide) with chemical shifts in ppm and using TMS (tetramethylsilane) as standard.

\section{${ }^{1} \mathrm{H}-\mathrm{NMR}$}

The ${ }^{1} \mathrm{H}$-NMR results for compound (3) Fig. (6) shown single signals at $14.09 \mathrm{ppm}$ was belonged to proton of $(\mathrm{NH})$ of indole ring ${ }^{20}$. A singlet signal at $9.40 \mathrm{ppm}$ was referred to proton atom of carbonyl group $(\mathrm{C}=\mathrm{O})^{21}$. As well as, single signal at $8.64 \mathrm{ppm}$ was attributed to proton of Schiff base group $(\mathrm{CH}=\mathrm{N})^{22}$ Signals were appeared in the region between (7.56-7.11) ppm were assigned to protons of aromatic ring for (3) compound ${ }^{23}$. Also singlet signals at 2.40 and $2.17 \mathrm{ppm}$ were assigned to two methyl groups at positions para and ortho on aromatic ring. Finally peak at $1.59 \mathrm{ppm}$ was belonged to six protons of two methyl groups ${ }^{24} .{ }^{1} \mathrm{H}$ NMR results of other compounds (1 and 2) are discussed and listed in table (2).



Fig. 6. 'H NMR spectrum of2-(5-Chloro-3,3-dimethyl-1,3-dihydro-indol-2-ylidene)-3-(2,4dimethylphenylimino)-propionaldehyde (3

Table. 2: The chemical shift in ppm to' ${ }^{1}$ NMR results of compounds (1-3)

\begin{tabular}{lccccccc}
\hline Compound No. & $\mathrm{NH}-$ & $\mathrm{C}=\mathrm{O}$ & $\mathrm{CH}=\mathrm{N}-$ & $\mathrm{Ar}-\mathrm{H}$ & Ortho $\mathrm{CH}_{3}$ & para $\mathrm{CH}_{3}$ & $2 \times \mathrm{CH}_{3}$ \\
\hline 1 & 13.99 & 9.42 & 8.69 & $7.63-7.23$ & - & - & 1.60 \\
2 & 13.95 & 9.43 & 8.65 & $7.66-7.33$ & - & - & 1.59 \\
3 & 14.09 & 9.40 & 8.64 & $7.56-7.11$ & 2.40 & 2.17 & 1.59 \\
\hline
\end{tabular}


${ }_{13}$ CNMR study

The ${ }^{13} \mathrm{C}$ NMR results supported ${ }^{1} \mathrm{H}$ NMR results for compound (3) as shown on Fig. 7. A signal at $187.81 \mathrm{ppm}$ and at $155.71 \mathrm{ppm}$ which belonged to the carbon atom of the carbonyl group $\underline{C}=\mathrm{O}$ and the carbon atom of the azomethine group $(\underline{\mathrm{C}} \mathrm{H}=\mathrm{N})$ respectively ${ }^{25}$. The signals were appear in range between $(149.45,147.41,135.21,134.23$, 131.42 , 129.25, 127.56, 127.23, 126.86, 121.61, 119.05 and 115.09 ppm) assigned to the carbon atoms of aromatic ring ${ }^{26}$. While the signal at 108.01 ppm was referred to carbon atom of $(\mathrm{O}=\mathrm{C}-\mathrm{C}=\mathrm{C})$ group $^{27}$, as well as a signal of carbon atom of $\left(\mathrm{CH}_{3} \mathrm{CCH}_{3}\right)$ group was observed at 54.23. In addition, signal two groups of methyl were observed at $21.26 \mathrm{ppm}$. Finally the signals of $p-\mathrm{CH}_{3}$ and o- $\mathrm{CH}_{3}$ were appeared at 20.17 and $17.34 \mathrm{ppm}^{28}$. The ${ }^{13} \mathrm{C}$ NMR results of the rest compounds (1 and 2) were given in the Table. 3.



Fig. 7. ${ }^{13} \mathrm{C}$ NMR spectrum of2-(5-Chloro-3,3-dimethyl-1,3-dihydro-indol-2-ylidene)-3-(2,4dimethylphenylimino)-propionaldehyde (3)

Table. 3: the chemical shift in ppm to ${ }^{13} \mathrm{C}$ NMR results of compounds (1-3)

\begin{tabular}{lcccccccc}
\hline Compound No. & $\mathrm{C}=\mathrm{O}$ & $\mathrm{CH}=\mathrm{N}-\mathrm{Ar}-\mathrm{CH}$ ring & $\mathrm{O}=\mathrm{C}-\mathrm{C}=\mathrm{C})$ & $\mathrm{CH}_{3} \mathrm{CCH}_{3}$ & $\mathrm{Para} \mathrm{CH}_{3}$ & $\mathrm{Ortho}_{3}$ & $2 \times \mathrm{CH}_{3}$ \\
\hline 1 & 188 & 156 & $149-118$ & 108 & 54 & - & - & 21 \\
2 & 187 & 156 & $148-117$ & 108 & 53 & - & - & 21 \\
3 & 187 & 155 & $149 .-115$ & 108 & 54 & 17 & 20 & 21 \\
\hline
\end{tabular}

\section{APT ${ }^{13}$ CNMR}

APT ${ }^{13} \mathrm{C}$ NMR results were further used to characterize the new three compounds. For example APT ${ }^{13} \mathrm{C}$ NMR results of compound (3) Fig. 8 shown signals for quaternary carbons and solvent which appeared at positive side (above of the spectrum). While $\mathrm{CH}$ and $\mathrm{CH}_{3}$ observed at negative side (below of the spectrum). ${ }^{1} \mathrm{H},{ }^{13} \mathrm{C}$ NMR and APT spectrum results for the new three compounds correspond well with the expected signals and are regular with the formation of these compounds.
In Vitro cytotoxicity effects of three indole derivatives

Cytotoxic activity against AMJ13 cell line

The synthesized of three new compounds $(1,2$ and 3$)$ were tested in vitro to determine their cytotoxicity toward breast human cancer cell line AMJ 13. Our results indicated that the cytotoxic activity of Compound(1) (Fig. 9) at high concentration $60 \mu \mathrm{g} / \mathrm{ml}$ appears higher cytotoxicity against AMJ13 cells gradually increase in its cytotoxicity according to exposure time at $72 \mathrm{~h}$ to inhibit $70 \%$ of the cells. While values of anticancer activity were obtained 
with the three concentrations 10,20 and $40 \mu \mathrm{g} / \mathrm{ml}$ at $72 \mathrm{~h}$ of exposure to be $60-70 \%$ as well. Further concentrations decreased, however, did not lead to the total cell death, since the cell viability was more than $90 \%$ compared to untreated cells, even at the lower concentration tested $(2-10 \mu \mathrm{g} / \mathrm{mL})$. Higher concentrations more than $60 \mu \mathrm{g} / \mathrm{mL}$ could not be prepared.
In case of compound (2) as presented in Fig. 10, the AMJ13 cells was sensitive to this derivative also at concentration $60 \mu \mathrm{g} / \mathrm{ml}$ and the lower concentrations at $72 \mathrm{~h}$ of exposure, the inhibition of AMJ13 cells was range to be $70 \%$. While at exposure time for 24 and $48 \mathrm{~h}$ the inhibition rate of cells were lowers than $60 \%$ for all the concentrations tested.





Fig. 8. APT ${ }^{13} \mathrm{C}$ NMR spectrum of2-(5-Chloro-3,3-dimethyl-1,3-dihydro-indol-2-ylidene)-3-(2,4dimethylphenylimino)-propionaldehyde

$24 \mathrm{hr}$.



$48 \mathrm{hr}$.

$10 \mu \mathrm{g} / \mathrm{ml}$

$20 \mu \mathrm{g} / \mathrm{ml}$

$40 \mu \mathrm{g} / \mathrm{m} \mathrm{I}$

$60 \mu \mathrm{g} / \mathrm{ml}$

$72 \mathrm{hr}$.

compound 1

Fig. 9. Cytotoxic activity of compound (1) against AMJ13 cancer cell line from prepared different concentrations for three different exposure times 




Fig. 10. cytotoxic activity of compound (2) against AMJ13 cancer cell line from prepared different concentrations for three different exposure times.

The cytotoxic activity of compound 3 was also observed to inhibit AMJ13 cells at concentrations 60,40 and $20 \mu \mathrm{g} / \mathrm{ml}$ for 48 and $72 \mathrm{~h}$ of exposures shows $70 \%$ range of cells inhibition rate. While at lower concentration $10 \mu \mathrm{g} / \mathrm{ml}$ also gives $60 \%$ inhibition rate at $72 \mathrm{~h}$ of exposure against AMJ13 cells as presented in Figure. 11.
Totally talking about the ability of all the compounds tested and concentration $10 \mu \mathrm{g} / \mathrm{ml}$ to be nominated against AMJ13 cell line growth at $72 \mathrm{~h}$ of exposure, choosing the lowest concentration that has the same ability to inhibit AMJ13 cells to higher ones let us to think again in using it as anticancer drug.



Fig. 11. cytotoxic activity of compound (3) against AMJ13 cancer cell line from prepared different concentrations for three different exposure times. 


\section{Cytotoxic activity against REF cell line}

The prepared of three new compounds (1, 2 and 3) also tested their cytotoxic activity in vitro against REF cell line. For compound 1, all tested concentrations were appear to inhibit cell growth specially at high concentration $60 \mu \mathrm{g} / \mathrm{ml}$ as time dependent to give $25 \%$ inhibition rate at $72 \mathrm{~h}$ of exposure while at lower concentrations the inhibition rates were lower means it could be safe to cell and let the REF cells grow normally specially at concentration $10 \mu \mathrm{g} / \mathrm{ml}$ as expressed in Figure 12



Fig. 12. Cytotoxic activity of compound (1) against REF cell line from prepared different concentrations for three different exposure times

While REF cells when exposed to different and concentration dependent. Only in concentrations concentrations of prepared compound (2) the cells after $24 \mathrm{~h}$ of exposure and at higher concentrations than $10 \mu \mathrm{g} / \mathrm{ml}$ started to be very sensitive and inhibition rate was time dependent also in this case 10 and $20 \mu \mathrm{g} / \mathrm{ml}$ and at $24 \mathrm{~h}$ of exposure the cells were live normally and did not affected by this derivative to range in its inhibition from $10-20 \%$ respectively as in Figure. 13.

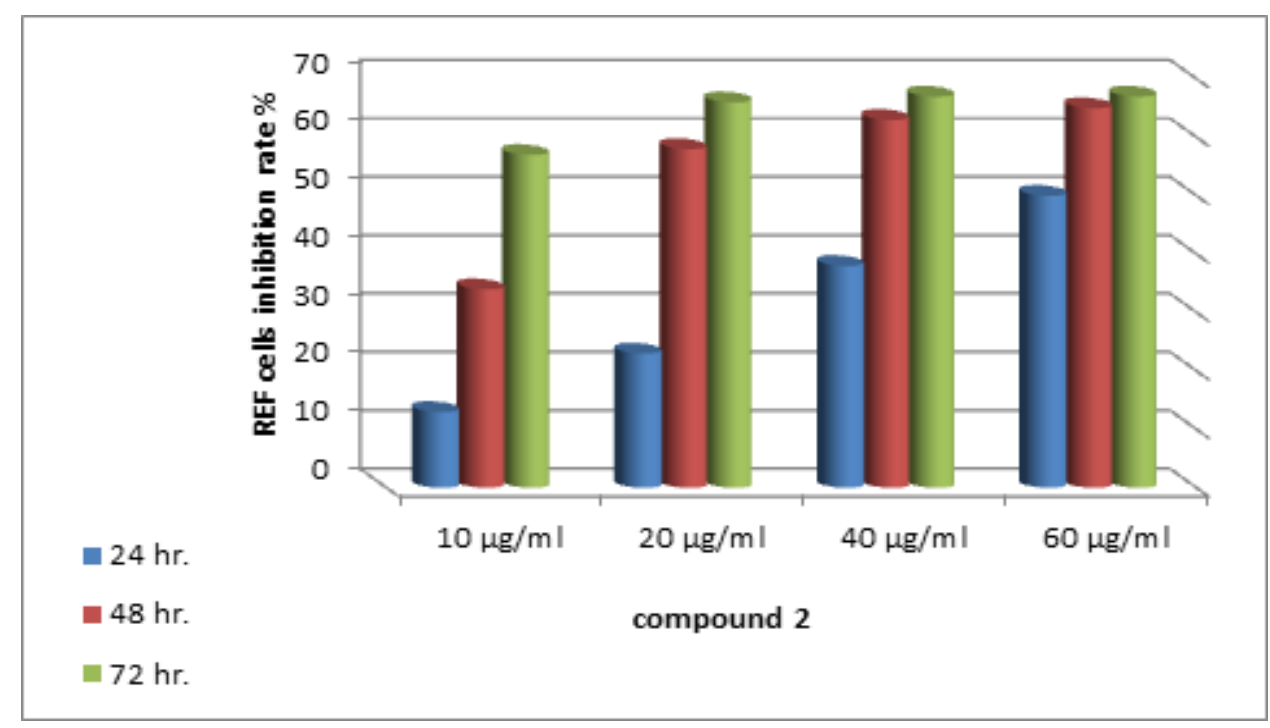

Fig. 13. cytotoxic activity of compound (2) against REF cell line from prepared different concentrations for three different exposure times. 
In compound 3 , concentration $10 \mu \mathrm{g} / \mathrm{ml}$ represented the safest concentration in the three exposure times to REF cells compared to other higher concentrations to give less than $15 \%$ inhibition rate at $72 \mathrm{~h}$ of exposure. Concentrations 20,40 and $60 \mu \mathrm{g} / \mathrm{ml}$ at $24 \mathrm{~h}$ of REF cells exposure also gives lower inhibition rate $33-37 \%$ respectively as presented in Figure. 14.



Fig. 14. cytotoxic activity of compound (3) against REF cell line from prepared different concentrations for three different exposure times

Reflecting from these results that compound (1) and its concentrations represent the safest to REF cell line growth did not show high inhibition rate during the exposure times. While only the lower concentration $10 \mu \mathrm{g} / \mathrm{ml}$ from compound (2) and (3) at $24 \mathrm{~h}$ of exposure give lower activity against REF cells.

\section{CONCLUSIONS}

Three new Schiff base indole derivatives [2-(5-Chloro-3,3-dimethyl-1,3-dihydro-indol-2ylidene)-3-phenylimino-propionaldehyde(1),3-(4Bromo-phenylimino)-2-(5-chloro-3,3-dimethyl-1,3dihydro-indol-2-ylidene)-propionaldehyde (2), and 2-(5-Chloro-3,3-dimethyl-1,3-dihydro-indol-2ylidene)-3-(2,4-dimethyl-phenylimino)propionaldehyde (3)] have been synthesized by reaction of 2-(5-Chloro-3,3-dimethyl-1,3-dihydroindol-2-ylidene)-malonaldehyde with aniline derivatives, The chemical structure of the synthesized compounds have been characterized and approved by TLC, FT-IR, ${ }^{1} \mathrm{H}$ NMR, ${ }^{13} \mathrm{C}$ NMR and $\mathrm{APT}{ }^{13} \mathrm{C}$-NMR techniques. The in vitro cytotoxicity of the compound prepared against breast cancer cell line AMJ13 revealed that the lowest concentration $10 \mu \mathrm{g} / \mathrm{ml}$ of 1,2 and 3 compounds has the ability to inhibit AMJ13 cells and in the same time safe to normal cell growth REF cell line. Let us to put a big highlight for further research on these compounds in cancer therapy models.

\section{ACKNOWLEDGMENT}

The authors thank the Iraqi Center for Cancer and Medical Genetic Research, Mustansiriyah University, and Department of Chemistry, Faculty of Science, University of Diyala, Iraq, for supporting this work.

\section{REFERENCES}

1. Apoorva, U.;Shefali, V.;Vakacharla, S V.;Prabha, J.;Anant. K. S.;Muralidharan, S.; Maheswaran, S.; Synthesis and characterization of $3 \mathrm{~d}$ and $4 \mathrm{f}$ metal complexes of Schiff base ligands. Polyhedron.(article in press),2013, 66, 87-96. 
2. Mohamed, M. I.;Hapipah, M. A.;Mahmood, A. A.; Pouya, H. Acute Toxicity and Gastro protective Effect of the Schiff Base, Ligand $1 \mathrm{H}$-Indole-3-ethylene-5-nitrosalicylaldimine and Its Nickel (II) Complex on Ethanol Induced Gastric Lesions in Rats Molecules. 2012, 17, 12449-12459.

3. Xavier, A.;Srividhya,N.; Synthesis and Study of Schiff base Ligands. Journal of Applied Chemistry. 2014,7, 2278-5736.

4. Deepa, S.;Anjani, K. T.;Sweta, S.;Gauri, S.; Pushpa, M.; Harish, C.; Anil, K. M.; Synthesis, characterization and biological activity of Schiff base analogues of indole-3carboxaldehyde. European Journal of Medicinal Chemistry. 2008, 43(1),160-165.

5. Fadhil, L. F.;Metal Coordination Behavior And Biological Activities of Indole And Quinazoline Derivatives. PhD thesis, Department Of Chemistry. Faculty of Science. University of Malaya. 2015.

6. Manish, R.;Kumanan, R.;Duganath, N.; Srinivasa,; M. M.;Nazeer, A.;Subramanyam, S.;Synthesis, Characterization and Pharmacological Screening of 2-methyl-1H Indole-3-Carboxylic Acid [2-(2-SubstitutedPhenyl)-4-oxo-thiazolidin-3-yl]-Amides Derivatives. International Journal of Chemical Sciences and Applications. 2011, 2(1),91-99.

7. Smith, R.;A.;Cokkinides, V.;Eschenbach, A.C.; American Cancer Society guidelines for the early detection of cancer. cancer Journal for Clinicians. 2002,52,8-22.

8. Xiong, L., Liang, B.;Bai, M.;Liu, J.; Impact of interaction between PPAR alpha and PPAR gamma on Breast cancer risk in Chinese Han population. Clinical Breast Cancer. 2016, 17, 336-340.

9. Alejandro, D. S.; Graciela, A.; David, F.;Monica, S. S.; Female Breast cancer in Central and South America. Cancer Epidemiology. 2016, 44, 110-120.

10. Al-Shammari, A.; Alshami, M.; Urman, M.; Almukhtar, A.; Yaseen, N.; Raad, K. and Hussien,A. Establihment and characterization of a receptor-negative, hormone-nonresponsive breast cancer cell line from Iraqi patient. Breast Cancer (Dove Med Press), 2015, 7, 223-230.
11. Baradarani, M.; Afghan, A.; Zebarjadi, F.; Hasanzadeh, K.; Joule, J.; The synthesis of 3,3-dimethyl-2-(1-aryl-1h-pyrazol-4-yl)-3hindoles. Journal of Heterocyclic Chemistry. 2006, 43, 1591-1595.

12. The National Toxicology Program (NTP) Interagency Center for the Evaluation of \& Alternative Toxicological Methods (NICEATM): Test Method Protocol for Solubility Determination Phase III. 2003. 1-10.

13. Butler, M.; Animal cell culture and technology. The basics. Oxford university press. New York, book. 2004, 2, 1-256.

14. Freshney, R. I.; Culture of animal cells. A manual for basic technique. Fifth ed. Willey liss. A Juhn wiley and sons. Inc Pup. New York, book. 2005, 1- 672.

15. Ngan,N. K.; Lo, K.M.;Synthesis, structure studies and electrochemistry of molybdenum (VI) Schiff base complexes in the presence of different donor solvent molecules. Polyhedron.2011, 30, 22-32.

16. El-Refaie, K.; Mohamed, A.; Khalil, S.; Ahmed, E.; Preparation of organophilic montmorillonite-based dimethyl amino benzaldehyde-Schiff-base as antibacterial agents. . Arabian Journal of Chemistry. 2016, 9, 574-585.

17. Montazerozohori, M.;Musavi, M.; Synthesis, spectral, crystal structural, antimicrobial, DNA interaction and thermal behavior of some new zinc halide complexes: 3Dsupramolecular structure of zinc bromide complex. Arabian Journal of Chemistry. 2014, 7, 656-667.

18. Rayees, A.S.;Mohmmad, Y.W.; Sheikh, S.A.; Adil, H.; Synthesis, characterization and biological screening of some Schiff base macro cyclic ligand based transition metal complexes as antifungal agents. Arabian Journal of Chemistry. 2016, 9, 743-751.

19. Razieh, M. A.; Mehdi, M.B.;Arash, A.; Synthesis of new heterocyclic compounds using 2-(4,7-dichloro-3,3-dimethylindolin-2ylidene)malonaldehyde.Current Chemistry Letters. 2013, 2, 13-20.

20. Faraj,F.L.;Khaledi, H.;Morimoto, Y.A.; TetradentateDiiminato Ligand Containing Phenolate Substituents: Flexivalent Coordination to MnIII, Colll, Nill, and Cull. European Journal of Inorganic Chemistry. 
2014, 33, 5752-5759.

21. Misra, U.; Hitkari, A.; Saxena, A.; Gurtu, S.;Shanker, K.; Biologically active indolylmethyl-1,3,4-oxadiazoles, 1,3,4thiadiazoles, $4 \mathrm{H}-1,3,4$-triazoles and 1,2,4triazines. Eurpean Journal of Medicinal Chemistry. 1996, 31, 629-634.

22. Suzan, A.M.;Wamidh, H.T.;Mohammad, S.;Mohammad,S.;Murad, A.;Synthesis, characterization, and antimicrobial activity of Schiff bases derived from benzaldehydes and 3,30-diaminodipropylamine. Arabian Journal of Chemistry. 2015, 8,850-857.

23. Zahedifard, M.;Faraj, F.; Paydar, M.;Synthesis, characterization and apoptotic activity of quinazolinone Schiff base derivatives toward MCF-7 cells via intrinsic and extrinsic apoptosis pathways. Scientific reports. 2015, 5, 497-514.

24. Alamgir, M.;Synthesis and reactivity of some activated heterocyclic compounds. Ph.D.
Thesis, The University of New South Wales Sydney, Australia, 2007.

25. Ngui, K.N.; Kong, M.L.;CheeSeng, R.W.; Synthesis, structure studies and electrochemistry of molybdenum(VI) Schiff base complexes in the presence of different donor solvent molecules. Polyhedron. 2011, 30, 2922-2932.

26. Muhammad, A.;Karamat, M.;Synthesis, Characterization and Biological Activity of Schiff bases..International Conference on Chemistry and Chemical Process. 2011, 10, 556-564.

27. Fadhil, L. F.; Hamid, K.;Hamed, K.; Hapipah, M. A.; Indole-Fused Epoxy-1,5-Diazocinesas Cancer-Selective Cytotoxic Agents. Heterocyclic Chemistry, 2017, 54, 2071-2074.

28. Sami, S.;Hooshang, V.;Abdolhossien, M.; Omid, L.; New $3 \mathrm{H}$-Indole Synthesis by Fischer's Method. Part I. Molecules. 2010, 15, 2491-2498. 